\title{
PORK PRODUCTION CHAIN: IMPORTANCE AND CHALLENGES FACED
}

\author{
Janice Reis Ciacci Zanella
}

Embrapa Suínos e Aves

Brazil is doing well in agriculture. We have availability of grains, abundant natural resources and diversity in the broad national territory, herd health and biosecurity stand out from the other livestock producing countries. There are funding for agricultural research, technology, technical assistance and extension. We have a sophisticated and diversified integration model. Therefore, Brazilian agriculture is efficient and competitors must observe closely.

Swine production in Brazil ranks fourth in the world for pork production and export. It produces 3,643 million tons and exports 555 thousand tons annually. In 2015 there were increases in domestic production by about $5 \%$ and $9 \%$ of exports. National Pork annual consumption per capita is $15.1 \mathrm{~kg}$, still considered low compared to other meats such as poultry (43 kg) and bovine (39 kg) (CIAS, 2016).

The rapid and constant evolution of new technologies and management tools makes swine farming a very dynamic activity. Consequently, increasing consumer demands for animal welfare and sustainability coupled with labor shortages pose major challenges (CIAS, 2016). Sustainability translates into balancing the economic, social and environmental tripods. It should account for investments, costs, employment generation, social responsibility and citizenship, preservation and management of natural resources, renewable energy, among others, respectively. It is to look at a systemic view of the whole. This concept of agribusiness was already defined in 1957 by John Davis and Ray Goldberg from Harvard University as "the sum total of all operations involved in the manufacture and distribution of farm supplies; production operations on the farm; and the storage, processing and distribution of farm commodities and items made from them". And it involves from scientific research to the marketing of food, fiber and energy (Davis and Goldberg, 1957).

Embrapa Swine and Poultry within a Embrapa's institutional program called "Agropensa" has sought to anticipate and follow trends that influence all the links of the productive chains of swine and poultry (CIAS, 2016). This vision of the future of the technological development of the Brazilian agriculture of 2014 - 2034 seeks, in addition to anticipating trends, but ensuring the permanent adjustment of the priorities of research and technology transfer, with a view to innovation.

The importance of swine farming for Brazil lies in several aspects. Among them that the swine industry is an organized segment of the Brazilian agribusiness, being a model for other chains and even other countries. It is a long chain, involve a complex of relationships and interrelationships with other activities (corn, soybean meal, vitamins, minerals, animal health, transport, buildings, machinery and equipment, advanced genetics, etc.), with a large multiplier effect of income and employment. Furthermore, it provides the internal supply of high quality protein. National swine production has experienced strong growth in recent years and is showing a trend towards expansion. Brazil is an important player in food production, especially meat, with a projection to expand by $35 \%$ in pork production, $23 \%$ in beef and 34\% in chicken meat by 2025 (Ministério da Agricultura, 2015). Pig farming contributes to the economic development 
of Brazil and more effectively in the regions where they operate, with important role in job creation, in support of family farming and the generation of income and revenue for the country (Filho, 2013).

Nevertheless, the big challenge is to feed 9 billion people worldwide by 2050 in a sustainable way, maintaining efficiency and competitiveness. Studies point out that population growth, increased urban population and world income will raise the demand for animal protein. Technology will be a great ally to multidisciplinary teams working in a collaborative, innovative and competent manner (FEEDINFO, 2013).

Due to the dynamism and interrelationship with other chains, swine production suffers from constant and profound changes with several threats that afflict the sector. The occurrence of climate change, the emergence in recent decades of diseases, mainly the zoonotic ones due to the concentration of production, urbanization, changes on the virulence of pathogens as well as the antimicrobial resistance (AMR). The advance of the globalization of markets has brought increasing volatility in the prices of grains and meat. There has never been such a great interdependence among nations. Protectionism, subsidies, requirements for disease and/or pathogen control, as well as control of residues or contaminants and requirements in environment and animal welfare are the result of this dynamism. This is aside from the rising wave of activism that strongly influences consumer opinion.

In the social and human field, the lack of skilled labor and the pursuit for better working conditions require the automation of processes at all levels of the chain. It's challenging and urgent the need to qualify the producers to improve business management, in particular to the family subsistence production, to improve income when accessing local markets and also reduce the risks to industrial production (FEEDINFO, 2013).

The constant search for increasing sustainability and competitiveness has as one of the main pillars the quality of products generated and animal health. Actors should seek the incorporation of good practices, both for the production and for the safety of foods. Important public policies should guarantee the improvement of the Brazilian product. Currently, Embrapa Swine and Poultry researches to review and modernize inspection systems for pork and poultry, as well as projects aimed at reducing the occurrence of foodborne diseases and mitigation of the risk of diseases that affect not only the herds, but the final consumer, be it Brazilian or the importing countries.

Another action of the Embrapa's team occurs in the surveillance, mainly in support of the Agriculture Ministry (MAPA) and accredited laboratories in the validation and development of techniques for diseases diagnosis and research in support of animal health surveillance. All this research effort is carried out together with industry and government to guarantee Brazil a sanitary standard of excellence, allowing exporting our products to dozens of countries in all continents.

In animal health, in addition to emerging diseases, a challenge is the increased attention to safe food production. According to the UN, WHO, FAO and OIE the high levels of antimicrobial resistance or drug resistance (AMR) seen in the world today are the result of overuse and misuse of antibiotics and other antimicrobial agents in humans, animals and crops, as well as the spread of residues of these drugs in soil, tilth and water. Within the broader context of AMR, antibiotic resistance is considered the largest and most urgent global risk requiring national and international attention. On the other hand, effective and affordable antibiotics are so vital to protect animal health and welfare and good veterinary medicine as they are to human health. Responsible and 
prudent use, good practices and implementation of established standards and guidelines should be followed (ONU, 2016).

In welfare of pigs, there is a tendency both internal and external in demanding minimum standards of animal welfare in the productive chains. This includes everything from handling in farms such as housing systems (gestations stalls for sows) and automation of production systems such as boarding and transport procedures, stunning systems and euthanasia (CIAS, 2016).

Genomic tools, gene edition and genetic selection will get animals more efficient, disease resistant and with better meat quality, with reduced fat, including odor reduction. The selection of animal genetics focusing on niches and specific markets will also be trend. Genomics through nutrigenomics will also be a useful tool to better express the potential action of biologically active substances in food and its effects on animal health. Other advances in nutrition may include the use of enzymes and intestinal modulators as probiotics and prebiotics. These advances bring much effect in improving digestibility as targeting the reduction or elimination of the use of antibiotic growth promoters and for prophylactic use.

For greater sustainability of swine industry, it will be necessary to create more rigorous environmental regulations, based on technical criteria validated by agricultural research. Thus, there will be a need to adopt water management technologies and to treat and recycle the waste generated by these activities: manure and litter, dead animal carcasses, slaughter waste, among others (CIAS, 2016).

The expansion of Brazilian pig farming will also require a greater integration of this chain with other agricultural and agroindustrial production systems through the use of animal production residues as fertilizers for the production of grains, forage and biomass (integrated crop-livestock-forest systems or ICLF). Alternatively, for the generation of co-products with higher benefit (added value), such as organomineral fertilizers, energy and biofuels, among others. In addition, the adoption of computing, remote sensing and information technology for the automation of equipment, practices and processes used in the environmental management of swine and poultry farming will be increasing. (CIAS, 2016). Sustainable production should be concerned with environmental impact. The global increase in temperature, the search for greenhouse gas (GHG) mitigation practices, the reuse and reduction of water use, biofertilizers and biogas are topics that will require more affordable technology (CIAS, 2016).

In summary, the lecture will address the main trends and the challenges for Brazilian pork production, as well as to discuss the role of agricultural research in this context, aiming to support the swine industry.

\section{Acknowledgments}

To Theme Groups and to Technology Transfer team of Swine and Poultry for prospecting the trends and challenges of the chain of swine. 


\section{References}

CIAS, E.S.e.A.-. 2016. Central de Inteligência de Aves e Suínos (Concordia).

Davis, J.H., Goldberg, R.A., 1957. A Concept od agribusiness. Division of research. Graduate School of Business Administration. Boston: Harvard University.

FEEDINFO 2013. AgriVision 2013 INTERVIEW: Paul Schickler, President, DuPont Pioneer. In Corporate News, News, B., ed.

Filho, J.I.d.S. 2013. Desempenho dos mercados avícola e suinícola brasileiros em 2013 e perspectivas para o futuro. In Anuário 2014 da Avicultura Industrial (Gessulli), 8.

Ministério da Agricultura, P.e.A., MAPA 2015. Projeções do Agronegócio - Brasil 2014/15 a 2024/25 Projeções de Longo Prazo (Brasilia, DF).

ONU 2016. At UN, global leaders commit to act on antimicrobial resistance, CENTRE, U.N., ed. 